\title{
Technical Feasibility of Using Construction Waste (Sand Fraction) as Stabilizing Agent in Sinop City (Brazil) Soil
}

\author{
Wdson Gurierizz de Oliveira Alves ${ }^{1}$, Gustavo Henrique Nunes ${ }^{1}$, João Paulo Boff Almeida ${ }^{1}$, \\ Francieli Schoenhals Delavy ${ }^{1}$, André Luis Christoforo ${ }^{2, *}$, Francisco Antonio Rocco Lahr ${ }^{3}$, \\ Julio César Beltrame Benatti ${ }^{1}$
}

\author{
${ }^{1}$ Department of Civil Engineering, University of Mato Grosso State (UNEMAT), Sinop, Brazil \\ ${ }^{2}$ Department of Civil Engineering (DECiv), Federal University of São Carlos (UFSCar), São Carlos, Brazil \\ ${ }^{3}$ Department of Structural Engineering (SET), São Carlos Engineering School, São Paulo University (EESC/USP), São Carlos, Brazil
}

\begin{abstract}
The development of the civil construction industry generates major problems, such as the production of construction waste. This complication is aggravated mainly in municipalities where there is no management and disposal policy, as it is the case of Sinop, Mato Grosso (MT), Brazil. A possible solution to this environmental problem in that municipality is the application of ground waste to sand fraction as stabilizer in order to increase resistance of the regional subgrade. The latter is characterized as having a low-bearing soil capacity. Furthermore, this strategy may allow for soothing of other problems, such as granular material extraction from the environment. This paper sought answers to improve the low-bearing soil capacity in Sinop, which was granulometrically and mechanically stabilized by having natural soil mixed with two percentages of construction waste: $25 \%$ and $50 \%$, with two compaction energies: normal and intermediate. Samples were subjected to tests for characterization and resistence. Results show relevant improvement in handling material characteristics. Natural soil, characterized as A-4 TRB, from bad to poor subgrade performance, and $12.2 \%$ CBR, with blend in three CBR cases as well as expansion, conformed to be sub-base material (CBR $>20 \%)$. Additionally, in one of the cases, it conformed to be base material (CBR $>60 \%)$. However, even though material with good resistance and bearing capacity was obtained, it was not possible to reach conclusions on its technical feasibility due to grain size not fitting ABNT NBR 15115 specification.
\end{abstract}

Keywords Construction Waste, Soil Improvement Techniques, California Bearing Ratio (CBR)

\section{Introduction}

Demographic growth of cities requires greater investment in urban infrastructure. One of the main investments is paving, which brings better quality of life and benefits to the population. The costs of urban paving are high due to the need for large-scale extraction of granular material to be applied to paving layers, for example. These layers are thicker and more expensive as the bearing capacity of the subgrade soil is worse.

In addition to high costs, extraction of granular material to construct base layers, sub-base, and for subgrade reinforcement in paving creates environmental problems. This is aggravated when material is available in deposits located in regions near environmentally protected

\footnotetext{
* Corresponding author:

alchristoforo@gmail.com (André Luis Christoforo)

Published online at http://journal.sapub.org/ijme

Copyright @ 2018 The Author(s). Published by Scientific \& Academic Publishing

This work is licensed under the Creative Commons Attribution International

License (CC BY). http://creativecommons.org/licenses/by/4.0/
}

areas $[1,2]$.

Sinop-MT is located in a region with low-bearing capacity of soils as subgrade soil [3]. Therefore, there is a need for soil improvement or replacement in order to allow for paving. Additionally, a large part of deposits located in the municipality are near Teles Pires River where environmental impacts associated with extraction are considerable.

An economic alternative to improve mechanical behavior of local soils is the implementation of stabilization techniques [4]. One modification technique of geotechnical properties is mechanical stabilization through compaction and mixing of soils with different characteristics [5].

According to Pereira et al. [6], compactation is the mechanical action imposed to the soil through the application of compressive strength. This results in reduction of void ratio with air-expulsion. This process aims to improve soil properties for engineering purposes, based on an increase in resistance and particle cohesion [7, 8].

It is extremely important to know the maximum bearing capacity of soil, keeping its functions preserved [9]. When the soil does not have satisfactory resistance, it is possible to improve its behavior by adding other soils and materials [6]. 
An alternative to improve the bearing capacity of local soil is the use of construction waste (RCC) as stabilizing granular material. This solution, in addition to minimizing the necessity of natural material deposits, contributes to another demand of this municipality: the production of construction waste associated with the unavailability of adequate places for its disposal [10, 11].

Thus, this study aims to offer an alternative for the improvement of the municipality's soil, while verifying the technical feasibility of using recycled aggregates, and using construction waste in sand fraction as a stabilizer of natural material. The modified soil can offer technical conditions and allow for its application in base layers, sub-base and subgrade reinforcement of urban paving.

\section{Theoretical Basis}

\subsection{Soils of Sinop-MT (Brazil)}

According to Pedology, the predominant soil in Sinop-MT is classified as red-yellow latosol, with quartz sands and plinthosols, as well as a laterite layer near Teles Pires River [12]. This laterite layer, also known as "gravel", is a type of material widely used for paving due to having good performance and good bearing capacity. The Transportation Research Board (TRB) classification characteristic of Sinop region (Table 1) suggests silt-clay material that has poor behavior as subgrade material [13].

Table 1. Properties of soil in Sinop by Simioni [14]

\begin{tabular}{cc}
\hline Characteristics & Indicators \\
\hline Liquidity Index - LI & $32 \%$ \\
Plasticity Index - PI & $6 \%$ \\
Group Index - GI & 7 \\
Percent passing through sieve \#200 & $70 \%$ \\
TRB classification & A-4 \\
\hline
\end{tabular}

According to Simioni [14], the optimum moisture content - $W_{o t}$ of natural soil was determined by means of trials in $23.40 \%$, apparent specific dry weight $-\gamma_{\text {dmax }}$ mean value was of $14.89 \mathrm{kN} / \mathrm{m}^{3}$, with CBR ranging from $6 \%$ to $20 \%$, thus obtaining a mean value of $13 \%$. The researcher concluded the studied soil cannot usually be used in base and sub-base layers in paving.

Table 1. Properties of soil (fine fraction) in Sinop by Uieno [15]

\begin{tabular}{cc}
\hline Characteristics & Indicators \\
\hline Liquidity Index - LI & NL (non-liquid) \\
Plasticity Index - PI & NP (non-plastic) \\
Group Index - GI & 0 \\
Percent passing through sieve \#200 & $29.8 \%$ \\
TRB classification & A-2-4 \\
\hline
\end{tabular}

Uieno [15], following the TRB method, classified the thin portion of soil removed from the gravel pit of Sinop City Hall (Table 2). Trials characterized the material as silty sand with excellent to good behavior for subgrade material. Additionally, Uieno's research [15] found CBR results ranging from $25.3 \%$ to $46.8 \%$, with mean value of $35.47 \%$. Machado [16], through trials performed for the same soil, determined $W_{o t}$ of $11 \%$, mean $\gamma_{d \max }$ of $19.20 \mathrm{kN} / \mathrm{m}^{3}$ and mean CBR of $25 \%$.

\subsection{Civil Construction Waste}

Civil construction waste can be mixed with soils for paving with the objective of improving geotechnical properties, reducing costs and minimizing environmental damage $[11,17]$.

The CONAMA 307 [18] resolution was introduced based on the need to implement guidelines to reduce environmental damage produced by construction materials, since their disposal in inappropriate places contributes to degradation of environmental quality. Managing those materials should provide social, economic and environmental benefits, considering technical and economic feasibility of production and use. Its 3rd Art. defines the classes they should fit: A, B, $\mathrm{C}$ and $\mathrm{D}$. Class $\mathrm{A}$ is the only one that can be used in paving layers, and may consist of materials from construction, demolition, renovation, paving repairs, as well as soil from land grading work. Some of the materials that fall under this classification are bricks, blocks, tiles, veneers, mortar, concrete, and tubes [18].

\subsection{Soil Stabilization for Paving}

Stabilization aims at improving soil properties, such as strength, permeability, deformability. Stabilized soil is defined as cases in which resistance gains are acquired with the use of additives, whereas improved soil is defined when improvement of other properties is sought, without significant gain of resistance [13]. The process has the function of transforming a given soil through artificial techniques, allowing it to serve different types of engineering work, in addition to its adaptation to different projects. The main methods employed for soil stabilization are shown in Figure 1.

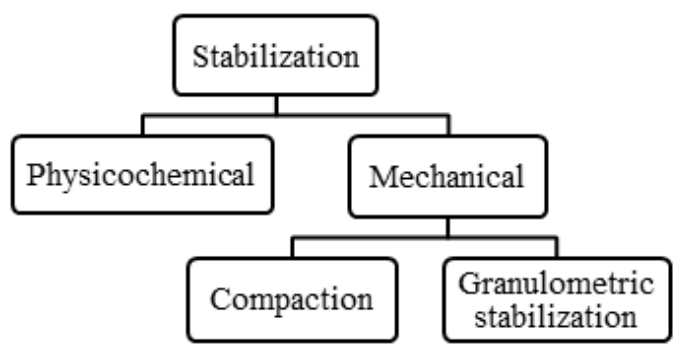

Figure 1. Methods of soil stabilization [13]

\subsection{Stabilization with RCC}

There are many examples of RCC application in Brazil as well as worldwide. Many countries have their own specifications for quality control in production and application of this material. Research on the application of recycled aggregates to paving has been conducted for many 
years and in many places [19].

The creation of Alternative Materials in Road Construction (ALT-MAT) was achieved by joining some European countries with the purpose of finding alternative materials for paving. The organization states that materials should be characterized according to each region, as local factors exert significant influence. Studies conducted by the organization obtained more satisfactory field-performance results than expected [20].

Hortegal et al. [21] state that RCC has demonstrated good behavior in pavement layers, thus becoming a very interesting and viable alternative, since it has great availability provided by existing recycling technologies. In addition, it is a renewable alternative capable of replacing natural materials, especially in low-volume traffic routes.

RCC in pavement layers has been used since the 1970s in the Netherlands, being a common practice [22]. In Brazil, the first register of a road paved with RCC was in the city of São Paulo in 1984, with RCC application in subgrade reinforcement layer. Execution was followed up by the Technological Research Institute of the State of São Paulo (Instituto de Pesquisas Tecnológicas do Estado de São Paulo), presenting satisfactory performance. In the same decade, a program was created and implemented in order to recycle materials from civil construction to paving. Studies and research led to the conclusion that it was material with good behavior for application to urban pavements [23, 24].

\section{Material and Methods}

\subsection{Soil}

The soil used in this research was collected from the subsoil of Estrada Nanci (Nanci Road) in Sinop-MT. Collection was made at the location shown in Figure 2, with the following geographic coordinates: $11^{\circ} 50 ' 36.2^{\prime \prime} \mathrm{S}$; $55^{\circ} 33 \prime 32.6 " \mathrm{~W}$.

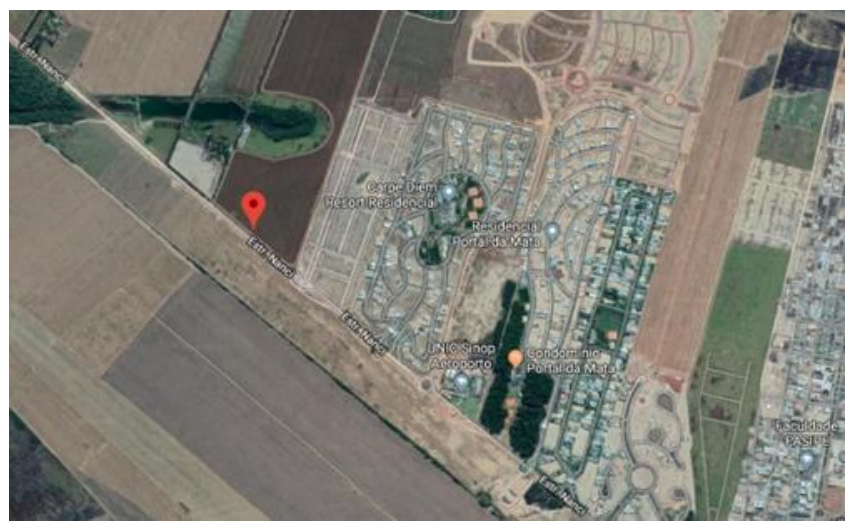

Figure 2. Soil collection site (source: Google Maps, 2018)

The sample was collected at about $0.06 \mathrm{~m}$ below the original height of the lane, with the aid of a shovel and a hoe. Later on, the collected soil was kept in plastic bags and transported to the Soil Lab at UNEMAT where it was dried under fresh air. The steps are illustrated in Figure 3.

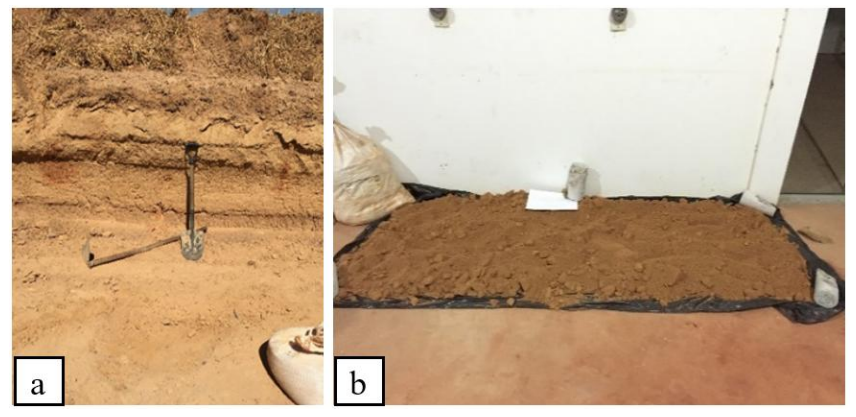

Figure 3. (a) Collecting soil; (b) Drying of soil

\subsection{Construction Waste}

The construction waste used (Figure 4) was collected from construction works of a private company in Sinop-MT. The material was milled by the company's own grinder.

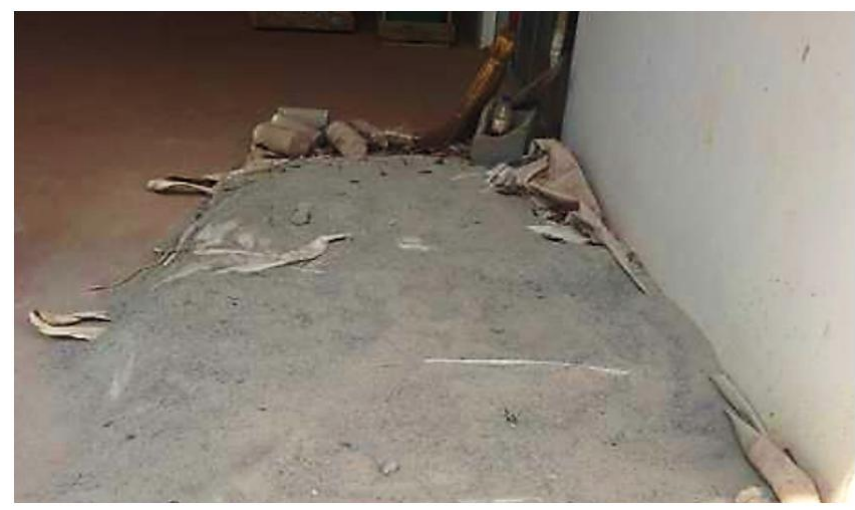

Figure 4. Drying of RCC

\subsection{Geotechnical Characterization}

Characterization of pure soil, pure construction waste and blends (25\% construction waste and $75 \%$ soil; $50 \%$ construction waste and $50 \%$ soil) was carried out by means of Atterberg limits tests [25, 26], granulometry [27], and TRB classification [13].
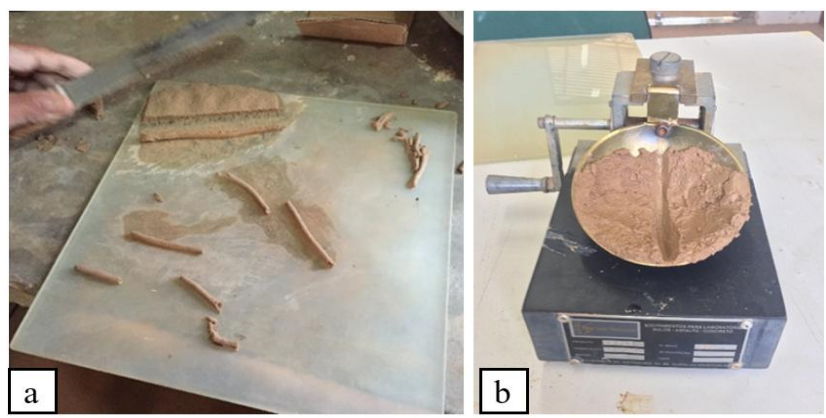

Figure 5. (a) Plasticity Index; (b) Liquidity Index

\subsection{Mechanical and Granulometric Stabilization with Construction Waste}

The behavior of materials was analyzed, according to ABNT NBR 7182 [28], with two different energies: normal and intermediate; as well as two blending percentages: $25 \%$ construction waste and $75 \%$ soil; $50 \%$ construction waste and $50 \%$ soil. Pure soil and pure construction waste analyses 
were also performed.

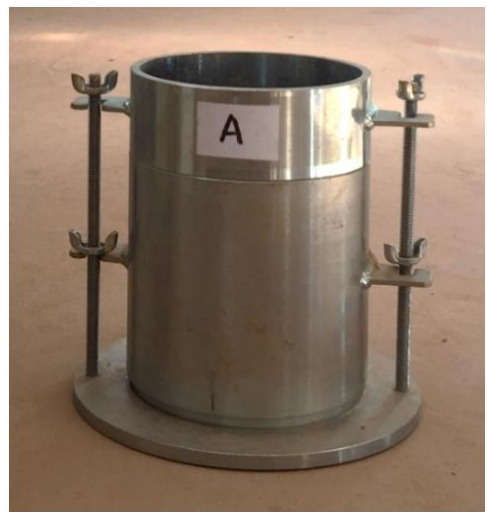

Figure 6. Small specimen

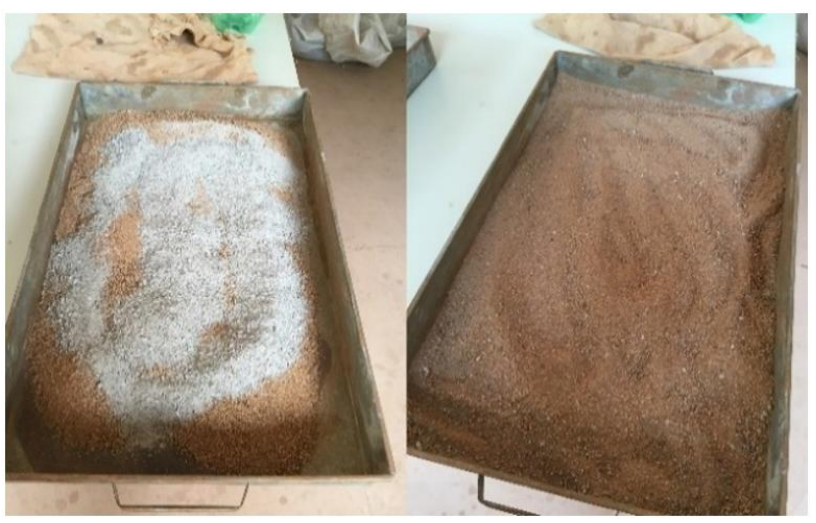

Figure 7. Homogenization of mixtures

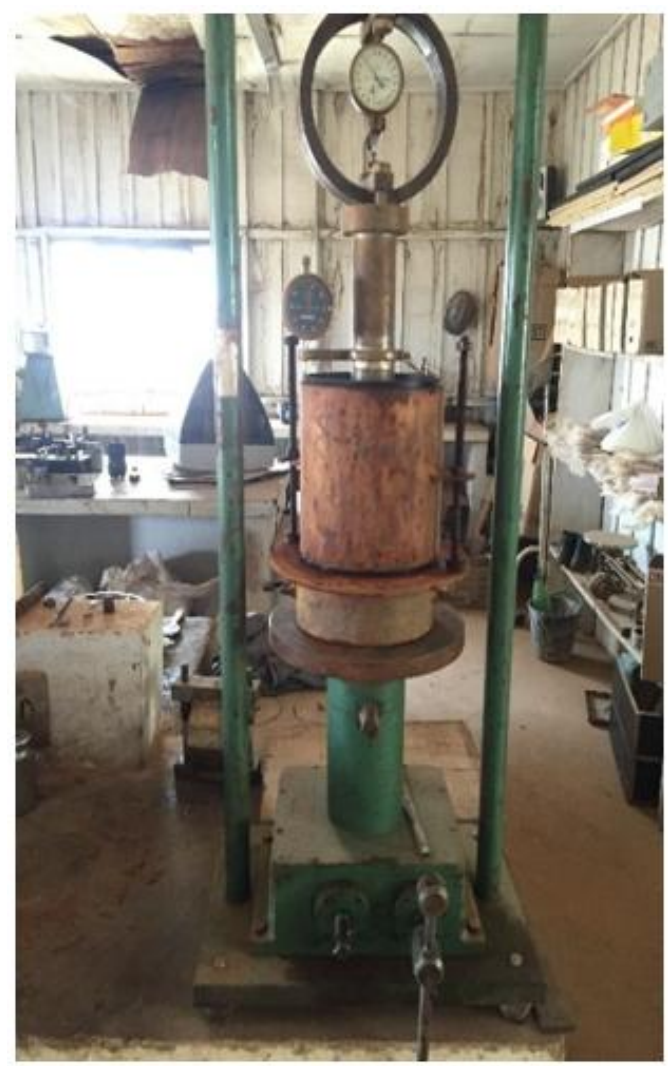

Figure 8. CBR test
In order to standardize the procedures, compaction tests were performed with the small cylinder $(10 \mathrm{~cm}$ in diameter and $12 \mathrm{~cm}$ in height), as shown in Figure 6 and specified by ABNT NBR 7182 [28]. Samples were homogenized (Figure 7) and subjected to compaction test. Pure soil curve with intermediate energy was adapted from the study conducted by Dalla Roza and Crispim [3].

\subsection{CBR e Expansion}

Two specimens were molded and ruptured for each material, one with normal energy and one with intermediate energy, optimum moisture point and maximum specific dry weight. The points were found through compaction curves in accordance with ABNT NBR 9895 [29]. Figure 8 shows the CBR test.

\section{Results and Discussion}

\subsection{Geotechnical Characterization}

Results from Atterberg Limits test and TRB classification are presented in Table 3.

Table 3. Summary of Atterberg Limits and TRB classification

\begin{tabular}{cccc}
\hline Material & LI $(\%)$ & IP $(\%)$ & TRB classification \\
\hline $\begin{array}{c}\text { Pure soil } \\
\text { 25\% construction } \\
\text { waste } 75 \% \text { soil }\end{array}$ & 23.00 & 27.00 & A-4 \\
$\begin{array}{c}50 \% \text { construction } \\
\text { waste } 50 \% \text { soil }\end{array}$ & 23.20 & NP & A-4 \\
$\begin{array}{c}\text { Pure construction } \\
\text { waste }\end{array}$ & NL & NP & A-4 \\
\hline
\end{tabular}

Classification of pure soil and blends show the addition of construction waste causes the soil to stop having a plastic behavior. However, even at a $50 \%$ construction waste addition rate, TRB classification remains unchanged.
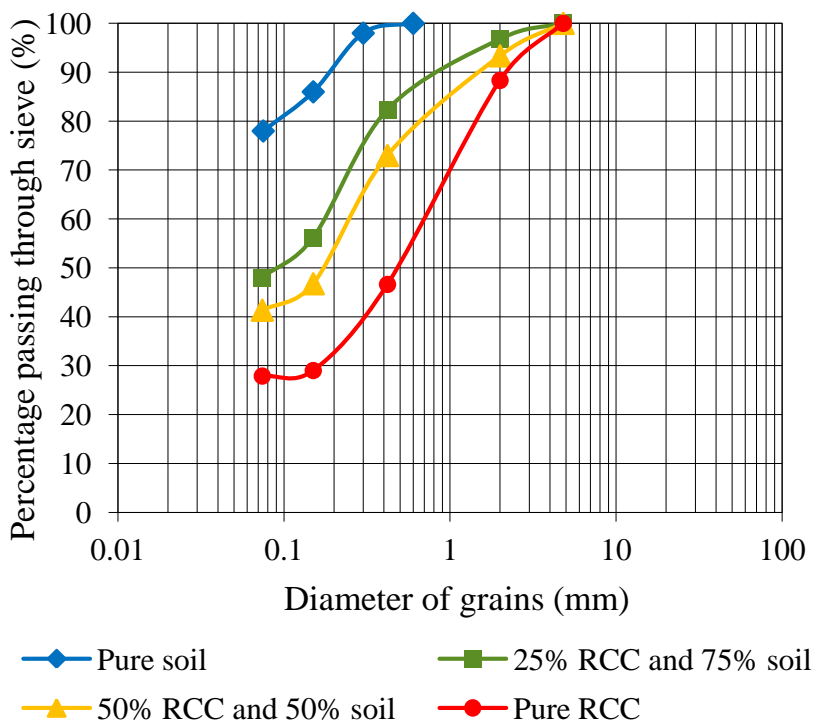

Figure 9. Granulometric curves of materials 
Figure 9 shows granulometric curves of materials.

By analyzing the granulometric curves, it is noted that as the construction waste percentage increases, the material becomes more graduated and has better particle size distribution, thus favoring its use. However, none of the blends complies with paragraph $\mathrm{C}$ from ABNT NBR 15115 [30], since all percentages passing through sieve \#40 are above the $40 \%$ limit.

\subsection{Mechanical and Granulometric Stabilization with Construction Waste}

Curves obtained from the compaction test with normal and intermediate energy are presented in Figures 10 and 11, respectively, and the corresponding results of $W_{o t}$ and $\gamma_{d m a ́ x}$ are shown in Tables 4 and 5.

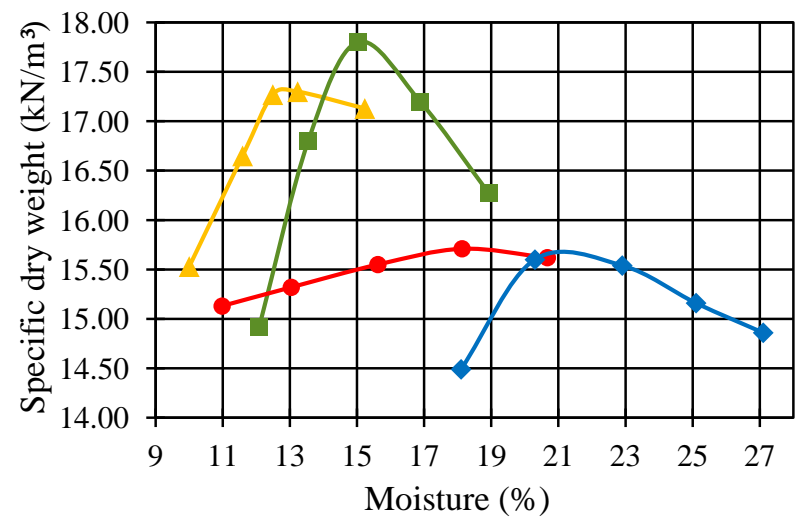

$\longrightarrow 50 \%$ RCC and $50 \%$ soil $\longrightarrow 25 \%$ RCC and $75 \%$ soil
$\longrightarrow$ Pure RCC

Figure 10. Compaction curves - normal energy

Table 4. Summary of compaction curves - normal energy

\begin{tabular}{ccc}
\hline Material & $\boldsymbol{W}_{\boldsymbol{o t}}(\boldsymbol{\%})$ & $\boldsymbol{\gamma}_{\boldsymbol{d m a ́ x}}\left(\mathbf{k N} / \mathbf{m}^{3}\right)$ \\
\hline Pure soil & 21.10 & 15.69 \\
25\% construction waste 75\% soil & 15.30 & 17.82 \\
$50 \%$ construction waste 50\% soil & 12.80 & 17.34 \\
Pure construction waste & 18.20 & 15.72 \\
\hline
\end{tabular}

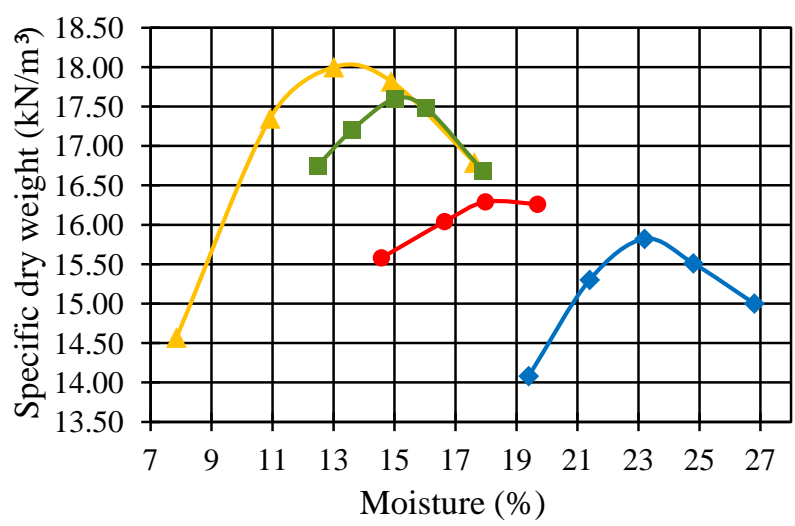

$\longrightarrow 50 \% \mathrm{RCC}$ and $50 \%$ soil $\longrightarrow 25 \% \mathrm{RCC}$ and $75 \%$ soil
$\longrightarrow$ Pure RCC
$\longrightarrow$ Pure soil

Figure 11. Compaction curves - intermediate energy
Table 5. Summary of compaction curves - intermediate energy

\begin{tabular}{ccc}
\hline Material & $\boldsymbol{W}_{\boldsymbol{o t}}(\boldsymbol{\%})$ & $\boldsymbol{\gamma}_{\boldsymbol{d m a} \boldsymbol{x}}\left(\mathbf{k N} / \mathbf{m}^{3}\right)$ \\
\hline Pure soil & 23.30 & 15.81 \\
25\% construction waste 75\% soil & 15.40 & 17.63 \\
$50 \%$ construction waste 50\% soil & 13.40 & 18.04 \\
Pure construction waste & 18.40 & 16.35 \\
\hline
\end{tabular}

When analyzing the compaction curves, it is possible to notice that for normal energy, adding construction waste leads to a decrease in optimum moisture and an upward tendency towards an increase in maximum specific dry weight, although higher $\gamma_{d m a x}$ was found in soil with addition of $25 \%$ of construction waste. It was also noted that pure construction waste presents a fairly higher value of optimum moisture. This fact may be associated to the porous structure of the material, which absorbs a significant amount of water.

Intermediate energy behavior is similar, with the ideal condition (maximum specific apparent dry weight) being the one noted in the blend having $50 \%$ of construction waste.

Altogether it is possible to affirm that both blends show a better behavior when compared to pure materials, thus suggesting that granulometric stabilization of soil with construction waste is technically efficient.

\subsection{CBR and Expansion}

Based on CBR tests results, it was possible to create a chart in which the result of CBR is associated with the percentage of construction waste addition, as shown in Figure 12. There was no expansion in neither tested samples. The summary of values is shown in Table 6.

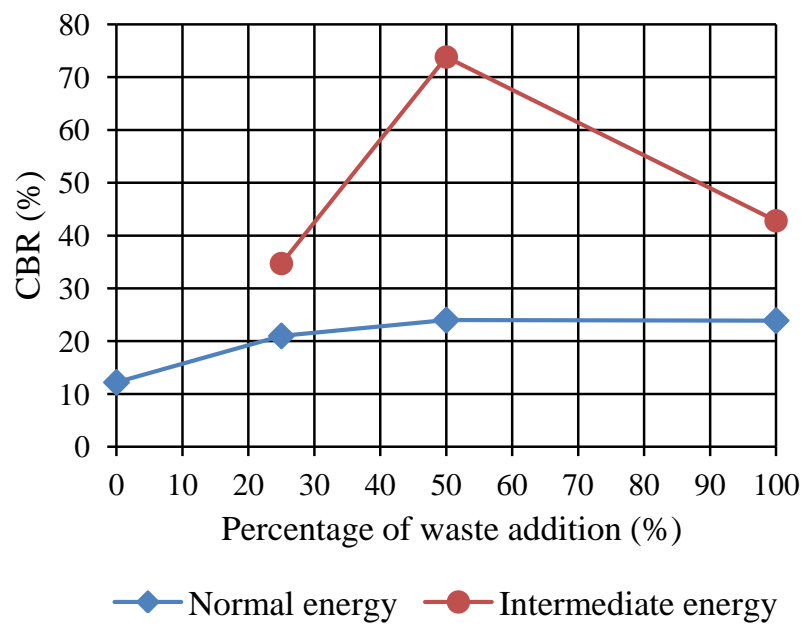

Figure 12. CBR versus addition of construction waste

When Figure 12 and Table 6 are analyzed, it is observed that for normal energy, the addition of construction waste raises soil bearing capacity up to approximately $50 \%$. For a larger portion of construction waste, the bearing capacity value remains stable. Consequently, in compliance with the result of compaction curves, it is noted that $25 \%$ of construction waste would be enough to stabilize the soil. 
Table 6. Summary of CBR values with normal and intermediate energies

\begin{tabular}{ccc}
\hline Material & \multicolumn{2}{c}{ CBR (\%) } \\
\cline { 2 - 3 } & $\begin{array}{c}\text { Energia } \\
\text { normal }\end{array}$ & $\begin{array}{c}\text { Energia } \\
\text { intermediária }\end{array}$ \\
\hline Pure soil & 12.20 & - \\
25\% construction waste 75\% soil & 21.00 & 34.70 \\
$50 \%$ construction waste 50\% soil & 24.00 & 73.80 \\
Pure construction waste & 23.90 & 42.80 \\
\hline
\end{tabular}

For intermediate energy, it is observed that the maximum value of bearing capacity occurs when $50 \%$ of construction waste is added, which is in agreement with the result of compaction curves, in which the addition rate presented the higher value of maximum specific dry weight.

The best result was the one obtained in the blend comprised of 50\% construction waste and 50\% intermediate energy soil. This blend enables the acquisition of a $74 \%$ CBR material. Thus, it is possible to compare it to excellent or good-behavior materials used for pavement layers. Additionally, the blend meets the CBR and Expansion specifications to be used in grade layers for traffic pavements up to $\mathrm{N} \leq 106$.

In all other cases of blend or pure construction waste, the material may be used as subgrade pavement layer based on CBR and Expansion requisites.

\section{Conclusions}

This paper analyzed the technical feasibility of using construction waste (RCC) in sand fraction as stabilizing agent in Sinop-MT (Brazil) soil. The natural soil of the city, known for its low-bearing capacity, is classified by TRB as A-4.

The application of soil blends and construction waste tested under two normative energies results in significant improvement in bearing capacity. However, compounds granulometry does not meet ABNT NBR 15115 [30] which lays down that the percentage of material passing through \#40 sieve must be under $40 \%$.

Data on CBR and expansion tests show the addition of $50 \%$ construction waste to intermediate energy enables the blend to be used for grade layers with CBR of 74\%. The blend containing $25 \%$ of construction waste with intermediate energy and even blends of $25 \%$ or $50 \%$ of construction waste with normal energy result in a CBR above $20 \%$, thus qualifying its application to subgrades layers.

The significant improvements in soil bearing capacity show the potential of applying civil construction waste in urban pavement layers. Nevertheless, there is a need for correcting blends granulometry in order to meet Brazilian guidelines.

Finally, the paper concludes that as construction waste (RCC) is added to the natural soil in question, CBR increases to some degree and then decreases. Even with $100 \%$ of construction waste (pure RCC), CBR is better than that of pure natural soil. This fact highlights how bad the bearing capacity of soil in Sinop-MT (Brazil) is.

\section{REFERENCES}

[1] Ure, A. M. Single extraction schemes for soil analysis and related applications, The Science of the Total Environment 1996, 178: 3-10.

[2] Jones Jr., J. B. Laboratory Guide for Conducting Soil Tests and Plant Analysis. Florida: Taylor and Francis Group, 2001, $364 \mathrm{p}$.

[3] Dalla Roza, A. E.; Crispim, F. A. Estabilização mecânica e granulométrica com pó de pedra de um solo de Sinop - MT. 36p. Universidade do Estado de Mato Grosso. Sinop, MT, Brasil, 2013.

[4] Portelinha, F. H.; Lima, D. C.; Fontes, M. P. F.; Carvalho, C. A. A. Modification of a lateritic soil with lime and cement: an economical alternative for flexive pavement layers, Soils and Rocks 2012, 35(1): 51-63.

[5] Onyelowe, K. C.; Okafor, F. O. A comparative review of soil modification methods, ARPN Journal of Earth Sciences 2012, 1(2): 36-41.

[6] Pereira, R. S.; Emmert, F.; Miguel, E. P.; Mota, F. C. M.; Rezende, A. V.; Leal, F. A. Estabilização mecânica de solos como alternativa na construção de estradas florestais de baixo custo, Nativa 2017, 5(3): 212-217.

[7] Trindade, T. P.; Carvalho, C. A. B.; Lima, D. C. Compactação de solos: fundamentos teóricos e práticos. Viçosa: UFV, 2008, $95 \mathrm{p}$.

[8] Hossain, K. M. A.; Lachemi, M.; Easa, S. Stabilized soils for construction applications incorporating natural resources of Papua new Guinea, Resources, Conservation and Recycling 2007, 51(4): 711-731.

[9] Rücknagel, J.; Götze, P.; Hoffmann, B.; Christen, O.; Marschall, K. The influence of soil gravel content compaction behaviour and pre-compression stress, Geoderma 2013, 209-210(11): 226-232.

[10] Assis, J. G.; Benatti, J. C. B. Escolha do Tipo de Fundação para Obras Residenciais Unifamiliares no Município de Sinop. 39p. Universidade do Estado de Mato Grosso. Sinop, MT, Brasil, 2014.

[11] Tam, V. W. Y.; Tam, C. M. A review on the viable technology for construction waste recycling, Resources, Conservation and Recycling 2006, 47: 209-221.

[12] Cidades. Diagnóstico das Condições de Saneamento nas Sedes dos Municípios do Estado de Mato Grosso Inseridos na Bacia Hidrográfica do Rio Xingu. Secretaria Nacional de Saneamento Ambiental, 2005, Ministério das Cidades, Brasil.

[13] Departamento Nacional de Infraestrutura de Transportes DNIT. Manual de Pavimentação. 3 ed. Rio de Janeiro, 2006.

[14] Simioni, C. F. Estudo da Estabilização de Solos com Cal na Região de Sinop/MT para fins de Pavimentação. 46p. Universidade do Estado de Mato Grosso. Sinop, MT, Brasil, 2011. 
[15] Uieno, M. S. Estudo da Estabilização Granulométrica de Solos na Região de Sinop/MT, para fins de Pavimentação. 48p. Universidade do Estado de Mato Grosso. Sinop, MT, Brasil, 2011.

[16] Machado, W. R. Estudo Experimental Referente ao Tratamento Solo-Cal com vistas à Pavimentação em Sinop/MT. 65 p. Universidade do Estado de Mato Grosso. Sinop, MT, Brasil, 2012.

[17] Cunha, S.C. Uso de Materiais não Convencionais para Base de Pavimentos Asfálticos no Município de Aparecida de Goiânia - GO. Dissertação (Mestrado em Engenharia Civil). Universidade Federal de Goiás. Goiânia, GO, Brasil, 2011.

[18] Brasil. Resolução CONAMA N ${ }^{\circ}$ 307, de 05 de julho de 2002. Dispõe sobre gestão dos resíduos da construção civil. Ministério do Meio Ambiente. Disponível em: <http://www.mma.gov.br/port/conama/res/res02/res30702.ht $\mathrm{ml}>$. Acesso em 8 de maio de 2018.

[19] Motta, R. S. Estudo Laboratorial de Agregado Reciclado de Resíduo Sólido da Construção Civil para Aplicação em Pavimentação de Baixo Volume de Tráfego. Dissertação (Mestrado em Engenharia Civil). Escola Politécnica da Universidade de São Paulo. São Paulo, SP, Brasil, 2005.

[20] Karle, S.; Modha, D.; Shah, M. Use of Recycled Material in Road Construction: Literature Review, International Journal of Engineering Science and Computing 2016, 6: 5550-5551.

[21] Hortegal, M. V.; Ferreira, T. C.; Sant'Ana,W. C. Utilização de Agregados Resíduos Sólidos da Construção Civil para Pavimentação em São Luís - MA. In: Pesquisa em Foco, 17(2): 60-74. São Luiz, MA, Brasil, 2009.

[22] Molenaar, A. A. A.; Van Niekerk, A. A. Effects of gradation, composition, and degree of compaction on the mechanical characteristics of recycled unbound materials. Transportation Research Record 2002, 1787: 73-82.

[23] Bodi, J.; Brito Filho, J. A.; Almeida, S. Utilização de entulho de construção civil reciclado na pavimentação urbana. In: Anais da Reunião Anual de Pavimentação 29:409-436. Rio de Janeiro, RJ, Brasil, 1995.

[24] Leite, F. C. Comportamento Mecânico de Agregado Reciclado de Resíduo Sólido da Construção Civil em Camadas de Base e Sub-base de Pavimentos. Dissertação (Mestrado em Engenharia de Transportes). Escola Politécnica da Universidade de São Paulo. São Paulo, SP, Brasil, 2007.

[25] Associação Brasileira de Normas Técnicas - ABNT. NBR 6459: Solo - Determinação do Limite de Liquidez. Rio de Janeiro, RJ, Brasil, 1984a.

[26] Associação Brasileira de Normas Técnicas - ABNT. NBR 7180: Solo - Determinação do Limite de Plasticidade. Rio de Janeiro, RJ, Brasil, 1984b.

[27] Associação Brasileira de Normas Técnicas - ABNT. NBR 7181: Solo - Análise Granulométrica. Rio de Janeiro, RJ, Brasil, 1984c.

[28] Associação Brasileira de Normas Técnicas - ABNT. NBR 7182: Solo - Ensaio de Compactação. Rio de Janeiro, RJ, Brasil, 1986.

[29] Associação Brasileira de Normas Técnicas - ABNT. NBR NBR 9895: Solo - Índice de Suporte Califórnia. Rio de Janeiro, RJ, Brasil, 1987.

[30] Associação Brasileira de Normas Técnicas - ABNT. NBR 15115: Agregados reciclados de resíduos sólidos da construção civil - Execução de camadas de pavimentação. Rio de Janeiro, RJ, Brasil, 2004. 